J OURNAL OF

French and Francophone Philosophy
REV VUE DE LA

philosophie française et de langue française

\title{
Black Orpheus and Aesthetic Historicism
}

On Vico and Negritude

Marina Paola Banchetti-Robino

Journal of French and Francophone Philosophy - Revue de la philosophie française et de langue française, Vol XIX, No 2 (2011) pp 121-135

\author{
Vol XIX, No 2 (2011) \\ ISSN 1936-6280 (print) \\ ISSN 2155-1162 (online) \\ DOI $10.5195 /$ jffp. 2011.495 \\ www.jffp.org
}

\section{(cc) EY-NC-ND}

This work is licensed under a Creative Commons Attribution-Noncommercial-No Derivative Works 3.0 United States License.

\section{ULIS D-Sunt}

This journal is operated by the University Library System of the University of Pittsburgh as part of its D-Scribe Digital Publishing Program, and is co-sponsored by the University of Pittsburgh Press 


\title{
Black Orpheus and Aesthetic Historicism
}

On Vico and Negritude

\author{
Marina Paola Banchetti-Robino \\ Florida Atlantic University
}

Hooray for those who never invented anything

Hooray for those who never discovered anything

Hooray for joy! Hooray for love!

Hooray for the pain of incarnate tears.

My negritude is no tower and no cathedral

It delves into the deep red flesh of the soil.

\section{Aimé Césaire}

Some scholars may find it odd to see the name of Giambattista Vico included in the title of an essay devoted to a study of the concept of negritude and its role as part of an African and Afro-Caribbean literary and political movement aimed at resistance to geographic and cultural colonization. Although Vico is temporally, culturally, and historically far removed from such important negritude poets as Aimé Césaire, Birgao Diop, and Léopold Sédar Senghor, to cite just a few, some of his ideas regarding the nature of history, culture, and myth and regarding the role of the poet in society can help us gain new and important insights into the poetry of negritude. What I hope to show, in this essay, is that the poetry of negritude and its role in the context of black resistance can be understood through the lens of Vico's anti-Cartesian epistemology and his claims regarding the important historical and cultural role of the poetic imagination.

In order to accomplish this task, I will first discuss Vico's aesthetic historicism and his response to the Cartesian paradigm that dominated the late $17^{\text {th }}$ and early $18^{\text {th }}$ centuries. I will then bring Vico's ideas regarding the role of imagination, poetry, and myth-making to bear on my discussion of 
negritude as it is developed in the writings of Aimé Césaire and Jean-Paul Sartre's important essay, Black Orpheus. In this discussion, I will focus on the role of the poet of negritude in the fight for black liberation, and I will relate these ideas to Vico's discussion of the function of poetry and myth in the creation of consciousness, culture, and community.

\section{Vico's Aesthetic Historicism}

Italian philosopher Giambattista Vico (1668-1744) is often hailed as "the first theorist of the human sciences, the founder of historicism, and one of the most powerful critics of the cognitive primacy or normativity asserted by a long line of philosophers for the natural sciences $[\ldots]^{\prime \prime} .^{2}$ As one of Descartes' most important critics and as the last defender of Renaissance humanism, Vico also stands as a beacon for anti-positivism. According to William Mills, "[against] the classic positivist thesis that all knowledge should approximate knowledge in the natural sciences, Vico's argument is not merely for the autonomy of our social understanding but for its epistemological superiority." 3 To this extent, in the great debate over the role of rhetoric versus logic, Vico clearly takes an anti-Platonic and antiCartesian position and favors the study of the arts of communication, as well that of history and of human institutions. Vico believes history to be the key to any science of humanity, because it provides an account of the birth, development, and decay of human societies and institutions. In order to understand earlier societies, Vico urges the study of language and myth. Because Vico places a strong emphasis on the role of imagination and mythopoetic creation in the development of history, his vision of world history can rightly be called an "aesthetic historicism." A.T. Grant explains:

Vico's synthetic method of historical criticism [...] offers an alternative view of history that connects imagination, metaphor, and myth to the 'creation' of [the gods] by the first theological poets. For Vico, reason need not displace myth since myth and reason are not contradictory, but complimentary ways of knowing that imply each other [...] [Vico] argued that though mythos antedates logos, nevertheless, the two are complementary and not antithetical ways of viewing the world [...] The first myth, that of Jove, is created by the theological poets by way of a metaphoric leap of imagination (fantasia). With this metaphoric leap, the first 'imaginative universal' is created, as well as language, ethics and community. ${ }^{4}$

In many ways, Vico's emphasis on the primordiality of myth anticipates many of Carl Jung's insights about the way in which the unconscious operates. For Jung, the unconscious communicates that which is unknown by way of symbols, and some of these symbols acquire a social function. As Gerald Slusser observes, for Jung "[a] truly living symbol compels 
unconscious participation and has a life-giving and life-enhancing effect [...] Symbols of this latter kind, woven into a mythic structure, are the functional motivators of culture. [...] Myth is the ruling element of the individual and society [as it] has been worked over, elaborated by conscious and group processes." 5 In his most important work, the Scienza Nuova (New Science) of 1744, Vico proposes that myth, poetry, and art are important means for understanding the spirit of a culture in a given epoch. This is why, for Vico, the search for truth does not begin with reason but with imagination. As Joseph Mali observes, for Vico, "mythos and logos, topica and critica are not essentially opposed, but historically complementary, and equally valid ... Vico ... forged a new scientific method which consisted in the figural signification of things, whereby they are represented in their iconical transformations in history." ${ }^{6}$

It would behoove us, at this point, to draw an important distinction that is implicit in Vico's work and that has been discussed by Ernst Cassirer and, more recently, by Paget Henry and Lewis Gordon. This is the distinction between reason understood as instrumental rationality and reason understood in broader, non-Cartesian terms. Instrumental rationality is precisely the conception of reason endorsed by Descartes and attacked by Vico. As Horkheimer, Adorno, and Marcuse argued, this Enlightenment conception of reason as instrumental rationality had a totalizing and dominating effect. ${ }^{7}$ According to the critique of the Frankfurt School, this "technological conception of reason gives rise to a one-dimensional world. Technological [and instrumental] reason is an enemy of the imagination and facilitates regimented modes of thought that all but render any alternative hopelessly impractical, if not altogether impossible." 8 To counteract the totalizing conception of reason as instrumental rationality, Gordon proposes distinguishing it from a conception of reason that is broader than mere instrumental rationality and that imposes constraints upon the latter. As such, this broader conception of reason is not opposed to mythos but, instead, encompasses it. Gordon writes, "we can easily become carried away in our own efforts to make the world completely rational, [as Ernst] Cassirer cautioned, and think of the living domain of reason only in terms of rationality ... To move beyond this compromised state of reason, [Paget] Henry argues, requires perceiving and engaging the distinctive rationality of myth. ${ }^{9}$ It will be seen, later in this essay, that this broader conception of reason, which is implicit in Vico's work, also informs the writings of Aimé Césaire and other negritude poets.

Vico believes that, when reason overcomes history and myth, it becomes an alienated abstraction and a precursor to barbarism. This is another aspect of Vico's thought that anticipates the importance of myth in the context of Jungian analytical psychology. Slusser tells us that, for Jung:

The collapse or loss of myth is a very serious matter indeed for an individual and for a society. It results more 
or less quickly in a profound loss or moral orientation and meaning for life. It is equally disastrous when the reigning myth, as it is with our nineteenth century myth of scientific materialism, pretends to be not myth but sober fact, and its nature is such as to cut one away from the living source of symbol and myth, the realm that Jung termed archetypal [...] The necessity for symbols and myth is clear. Life cannot properly proceed without them. ${ }^{10}$

Therefore, for Vico like Jung, the development of instrumental rationality is the last stage in the development of consciousness and it is not necessarily the highest stage. He laments the loss of poetry's true function, which is that of creating myth, of conjuring the gods into Being, and of sublimating desire for the sake of civilization. According to Grant, "Vico would agree with Derrida that metaphysics ... actively sought to erase the story and substitute 'clear and distinct ideas' as the purview of philosophy and theology. But Vico sees culture as an onion: if one peels away layers of myth and language, one eventually has no onion at all, since myth, language, and community are inextricably bound together." 11

In the next section of this essay, I will explore how these Vichean ideas about the nature of poetry and myth can help us gain new insights into the poetry of negritude and into how this poetry accomplishes the task of imaginatively reconstituting the identity, culture, and history of black people in the midst of both geographical and cultural colonial domination. I hope to show that this poetry fits the model of a myth-making poetic in Vico's sense, and that the myth-making power of the negritude poets actively evokes and elevates black identity, and effectively undermines white cultural domination.

\section{Vico, Black Orpheus, and Negritude}

Although Vico antedates the negritude movement by at least two centuries, it is interesting to note how well his ideas harmonize with those embraced by the leading figures of negritude. For example, many themes in Aimé Césaire's essay "Poetry and Knowledge" are reminiscent of Vico. There Césaire offers a staunch critique of the rationalistic paradigm that has dominated European philosophy since the early Enlightenment. This paradigm, as Stephen Toulmin explains, has "imposed on philosophy a certain epistemic picture, of Man the Rational Knower facing Nature the Unchanging Object of Knowledge."12 Like Vico, Césaire recognizes the value of law and science but also rejects the dominance of the Cartesian conception of knowledge that destroys the mythopoetic imagination. Affirming the broader notion of reason discussed above, Césaire explains that "science rejects myth where poetry accepts it ... Myth is inferior in precision [to science]. But it is superior in richness and sincerity. Only myth 
satisfies man in his entirety: his heart, his reason, his taste for the part and the whole, for the false and the true, because myth is all these things at once." ${ }^{13}$ Césaire would also agree with Vico's view on the nature of language. For both thinkers, understanding language is prior to understanding humanity, and the knowledge of language and rhetoric is superior to the sort knowledge that can be acquired scientifically. Césaire thus looks forward to a time in which the study of language will be antecedent to the study of nature:

[L]ittle by little, man became aware that, besides the scientific, half-starved knowledge, there was another kind of knowledge. A satisfying knowledge [...] In the same way that the new Cartesian algebra made possible the construction of a theoretical physics, so an original handling of the word can give to every possible moment a new theoretical undercurrent of which poetry would already give a fairly good idea. Then the new time will come when the study of language will condition the study of nature. ${ }^{14}$

Like Vico, Césaire believes that the mythopoetic imagination provides more profound knowledge than science because it dives deep into the nature of Being. He states that "[a]t the basis of poetic knowledge [is] an astonishing mobilization of all cosmic and human forces ... What governs the poem is ... the entirety of experience." ${ }^{15}$ Césaire, like Vico, believes that myth binds us to the source of Being and the mythopoetic imagination connects us to nature, to our ancestors, and to our history. In Césaire's words, "[n]ow is the moment to remember that the unconscious which all true poetry appeals to is the receptacle of the kinship that, originally, united us with nature [...] And one can say that all great poetry, without ever renouncing its humanity, at a very mysterious moment ceases to be strictly human to begin being truly cosmic." ${ }^{16}$ Both Vico and Césaire emphasize the constitutive role of the poet in the creation of cultural myth and, once again, we find intimations of these ideas in the thought of Carl Jung. J'Nan Morse Sellery tells us that, according to Jung, "[p]oets seek to create a bridge from the invisible to the visible and from the specific to the universal [...] Mythologies are a necessary ingredient in humanity's discovery of the transcendental spirit. Poets have long known ... that "life cannot properly proceed without" symbols and myth." ${ }^{17}$ The poetry of negritude represents the genius of those poets who overcame the reigning myths that informed the geographical and cultural colonization of the African people, both on the continent of Africa itself and in the diaspora, by creating a living countermyth that emerged precisely from "the insights, sentiments, thought, and vision" of black poets.

One of the most important works to introduce the poetry of negritude to a wide audience was Léopold Sédar Senghor's 1948 Anthologie de la 
nouvelle poésie nègre et malgache (Anthology of the New Black and Malagasy Poetry). Jean-Paul Sartre offered his essay Orphée Noir (Black Orpheus) as an introduction to the work. There Sartre discusses and embraces the concept of negritude as a necessary development in the anti-colonial movement and proceeds to evaluate the role of negritude in the context of his dialectical materialist conception of history. The choice of the essay's title is quite telling of how the poetry of negritude should be understood, on Sartre's view. He explains:

I shall call this poetry "Orphic" because the [black man's] tireless descent into himself makes me think of Orpheus going to claim Eurydice from Pluto ... it is by letting himself fall into trances, by rolling on the ground like a possessed man tormented by himself, by singing his angers, his regrets, or his hates, by exhibiting his wounds, his life torn short, by becoming most lyrical, that the black poet is most certain of creating a great collective poetry. ${ }^{18}$

The poetry of negritude, according to Sartre, is a poetry of liberation for black people. The white worker cannot articulate his liberation from the class struggle in the form of imaginative poetic creation, on Sartre's view, because the narrative of the working class is the narrative of dialectical materialism and of the universal man of the workers' international. This narrative is instrumentally rational but, as such, cannot give rise to imaginative poetic articulations.

Vico's thought can help us shed some new light on why the mindset referred to by Sartre as that of the white working class would be antithetical to poetic creation. According to Patrick Hutton, "[f]or Vico, it is not man's existential involvement with the physical world as such which is crucial for the way in which man fashions his own nature ... the environment is only the potential occasion for a process of creation which is entirely the product of imagination ... imaginative creation is the means by which man's consciousness of the world unfolds. ${ }^{19}$ Furthermore, in Vico's opinion, the product of mythopoetic imagination is superior to that of instrumental reason. Although hypothetico-deductive reasoning may produce mathematical theories through which human beings can acquire certainty and truth, this knowledge does not concern the real world. Vico's views concerning the nature of mathematical reasoning as limited were to be echoed, centuries later, in Nietzsche's question: "Are the axioms of logic adequate to reality or are they a means and measure for us to create reality, the concept of 'reality' ourselves?" 20 Nietzsche's own answer to this question is that "[l]ogic is the attempt to comprehend the actual world by means of a scheme of being posited by ourselves; more correctly, to make it formulable and calculable for us. [Logic] depends on presuppositions with which nothing in the real world corresponds." 21 Vico would agree with this and would probably add that, because hypothetico-deductive reasoning places 
limitations on thought, instrumental reason cannot produce the kind of imaginative poetry that is capable of conjuring Being out of nothingness through language. The instrumental reason referred to that Gordon distinguishes from a broader conception of reason that is not opposed to, but rather encompasses, mythos. Césaire would certainly concur with Vico's, Nietzsche's, and Gordon's judgments in this regard. In fact, Césaire explains that hypothetico-deductive thought limits poetic creation precisely because the principles that make it so successful in the context of logic are the very same principles that stifle the mythopoetic imagination. "The safety railings are there: the law of identity, the law of contradiction, the principle of excluded middle. Precious safety railings. But also singular limitations." 22 In fact, both Vico and Césaire would doubtlessly subscribe to Louis Simon's claim that "atrophy of the imagination is an illusion created by the embrace of rational, scientific ways of thinking and the rejection of complex, non-paradoxical modes of thought." 23

Returning to Sartre's point that the liberation of the white working classes could never be effected or expressed through the poetic imagination, Sartre then claims that, on the other hand, the liberation of the black man from colonialism and racial oppression requires poetic and aesthetic expression. Sartre states that

before black peasants can discover that socialism is the necessary answer to their present local claims ... they must think of themselves as black men ... Thus subjectivity reappears: the relation of the self with self; the source of all poetry, the very poetry from which the worker had to disengage himself. The black man who asks his colored brothers to "find themselves" is going to try to present to them an exemplary image of their negritude and will look into his own soul to grasp it. ${ }^{24}$

Sartre adds that the black poet is the true voice of liberation for all black people because, through his artistic creation, he is able to construct a new meaning for blackness, a new meaning that cleanses blackness of the negative connotations given to it by the white world. Blackness, in the poetry of negritude, is constituted as something beautiful, something good, and something free. The poetry of negritude, written by black poets for black people, represents the myth-making power of the black soul and effects a rediscovery of black subjectivity. In this sense, the black poet becomes a lyrical prophet and conjurer of black subjectivity. In order to rediscover blackness, Sartre tells us, black poetry must conjure the black soul into Being, since white domination has worked towards destroying the unity, community, history, and culture of the children of Africa who were taken as slaves and colonized. The white paradigm has attempted to effect the destruction of the black soul through the transformation of black subjects into objects and the strategies used have been many. The answer to the 
resurrection of the black soul is, therefore, not the positivistic science that worked at the service of exorcising the soul out of blackness. What are needed, instead, are the alchemy of language and the incantatory chants of the black poet as he calls forth the gods of his ancestors. Sartre writes:

The black men of Africa ... are still in the great period of mythical fecundity, and French-language black poets are not just using their myths as a form of diversion as we use our epic poems: they allow themselves to be spellbound by them so that the end of the incantation, negritude magnificently evoked - may surge forth. This is why I call this method of 'objective poetry', magic, or charm. ${ }^{25}$

The magical creative power of the black poetic imagination is evident in the poet's praise of the black woman for her beauty and her sensuousness and for being the mother of all black people. The black woman's generative significance acquires mythical proportion through the words of the poet, and for Senghor the black woman represents Africa itself. Thus, the poet's conjuring power is also reflected in his constitution of Africa as the mythical motherland to which one dreams to return. This Africa is not an Africa that has ever been experienced by the poets of negritude, since many of them are either French-born or francophone poets of the Caribbean. It is not these poets' intention, however, to empirically describe an Africa that they know or that even exists. Rather, they are imaginatively creating a mythic and mystical Africa that is the lost homeland of all black people. In other word, their goal is not an ontical description but an ontological summoning of Being.

Interpreting this in Vichean terms, the poetry of negritude fulfills the true function of mythopoetic creation through which the spirit, character, and history of a people are constituted out of the nothingness of exile, out of the anonymity of otherness. The gods are conjured, and the Being of a mythical land of ancestors becomes part of the collective memory of an outcast people. In "Poetry and Knowledge," Césaire writes that what emerges from the creations of poetic genius are "the old ancestral depth. Ancestral images which only the poetic atmosphere can bring up-to-date for the purposes of decipherment. The buried millenarian knowledge ... in this sense all the mythologies the poet happens upon, all the symbols he gathers and gilds are true." 26 The power of the poet, to which Césaire appeals, would be explained by Vico by saying that "[m]yths have explicit modes of perception out of the flux of reality, and thus establish necessary directions for all subsequent development of human consciousness ... Such myths are the imaginative creations of an elite of poetic genius ... [and] become the ideal models for all social institutions." 27

The poetry of negritude is a different kind of poetry from that produced by the white poets, because black poetry is not a bourgeois artistic creation 
meant for individualistic self-expression or for entertainment. Rather, the poetry of negritude has what Vico would call a myth-making purpose. It creates the being of a free and autonomous blackness that lives in a mythical world in which whiteness becomes irrelevant. The poet of negritude conjures such a world into Being by writing for black eyes only. However, this positive ontological function of the poetry of negritude is accompanied by an equally important negative ontological function. Through the poetry of negritude, the white man becomes a void and the white world is conjured out of Being. In this poetry, the voyeuristic gaze of whiteness is absent, and the white reader feels as an intruder in a place where he does not belong. The white man is neither welcome nor unwelcome because his presence, as well as his thoughts and his feelings, no longer matter. Thus, the black poet constitutes, sings, and praises an authoritative black subjectivity and renders whiteness meaningless.

It is interesting to observe how Sartre, as a white man, experiences the poetry of negritude, since this indicates how truly successful this poetry is at achieving its aims. As Sartre confesses, when he reads this poetry, he experiences the whiteness of his skin as a paleness, as an absence, as something that, if the white coating imprisoning his skin were removed, would reveal a beautiful black skin. Thus, whiteness comes to represent a negativity, a lack. "A black poet - unconcerned with us, whispers to the woman he loves ... and our whiteness seems to us to be a strange livid varnish that keeps our skin from breathing - white tights ... under which we would find real human flesh the color of black wine if we could remove them." 28 In the poetry of negritude, "Being [ $\hat{E}$ tre] is black, Being is made of fire, we [the whites] are accidental and far away, we have to justify our mores, our technics, our undercooked paleness of verdigris vegetation ... we will not be able to become part of the totality from which those black eyes exile us, unless we tear off our white tights in order to try simply to be men." 29

In the hands of the poets of negritude, French, the language of the colonizer, is turned upon itself and is, thereby, transformed into the colonized's language of liberation. This is why Sartre states that "black poetry in the French language is, in our time, the only great revolutionary poetry." 30 Through this poetry, French becomes the language whereby the Frenchman himself is made irrelevant and whereby the categories of the white world are inverted, turned on their heads, and falsified. Black is good, black is innocent, darkness is purity. According to Sartre,

[s]ince the oppressor is present in the very language that they speak, [the black poets] will speak this language in order to destroy it. The contemporary European poet tries to dehumanize words in order to give them back to nature; the black herald is going to de-Frenchify them; he will crush them, break their usual associations, he will 
violently couple them ... Only when they have regurgitated their whiteness does he adopt them, making this ruined language a solemn, sacred super-language, Poetry. ${ }^{31}$

This turning of the colonizer's language upon itself conforms to Vico's conception of the rhetorical and creative function of language. For Vico, it is only through the language of poetry that one can evoke the silence necessary to invoke Being. Sounding almost as though he is channeling Vico, Sartre tells us that "[n]o one better stated that poetry is an incantatory attempt to suggest Being by the vibratory disappearance of the word: by insisting on his verbal impotence, by making words mad, the poet [of negritude] makes us suspect that beyond this chaos which cancels itself out, there are silent densities; since we cannot keep quiet, we must make silence with language." ${ }^{32}$

This view is consistent with Vico's claim that "[t]he poet does not imitate the appearance of reality but, rather, evokes [or conjures] its form from his own consciousness. In this sense, poetry is man's essential metaphysical activity." 33 In Sartre's words,

Being comes out of Nothingess like a penis becoming erect; Creation is an enormous perpetual delivery; the world is flesh and the son of flesh; on the sea and sky, on the dunes, on the rocks, in the wind, the [black man] finds the softness of human skin; he rubs himself against the sand's belly, against the sky's loins: he is "flesh of the flesh of this world"; he is "porous to all its breaths," to all its pollens; he is both Nature's female and its male; and when he makes love with a woman of his race, the sexual act seems to him to be the celebration of the Mystery of Being. ${ }^{34}$

Yet, for all the myth-making and imaginative creativity of its poetry, Sartre does not believe that the negritude movement represents a new golden age for black people or a final stage in their liberation. According to Sartre, once black subjectivity has been rediscovered and liberated from the yoke of racial oppression, the class struggle will still remain to be fought, and the black man must renounce the blackness of his subjectivity, embrace his identity as a proletarian worker, and realize that socialism is his true liberation. Sartre claims that, eventually, the concept of negritude is, to invoke Stanley Fish's term, a self-consuming artifact. Sartre tells us that "negritude is not a state, it is a simple going-beyond-itself, it is love. It is when negritude renounces itself that it finds itself." 35 After being so imaginatively conjured through the mythopoetic language of these poets, this black subjectivity must eventually be replaced by the raceless universal man. Sartre's understanding of negritude, however, occurs in the context of 
the larger international class struggle and is, therefore, tainted by that very perspective.

Frantz Fanon raises a brilliant critique of Sartre's claim regarding this self-immolation of the black self. Fanon begins by wondering how this new poetics, whose intentional function was to constitute a new meaning for the existence of the black man and to open the door to new possibilities and projects, could be merely instrumental within the historical dialectic. Would it not indicate an ultimate failure of negritude if it were merely a dialectical step toward the ultimate annihilation of that very identity that it values and affirms? By homogenizing the African situation with that of the European proletariat and by seeing negritude as a mere means to an ultimate universalizing end defined by a global dialectic, Sartre is extinguishing the uniqueness of the being of the black man. Ironically, by liberating himself through negritude for the sake of a homogenizing universal class struggle, the black man risks becoming once again what he was under the yoke of racial oppression: In Ralph Ellison's words, an invisible man. Fanon states:

Black Orpheus is a date in the intellectualization of black existence. And Sartre's error has been not only to seek the source of the source, but in some way to dry up this source ... The dialectic that introduces the necessity at the cost of my freedom expels me from myself ... In terms of consciousness, black consciousness is immanent to itself ... Jean-Paul Sartre forgets that the black man suffers in his body differently from the white man. ${ }^{36}$

It is interesting, at this point, to examine how Giambattista Vico might respond to Sartre's claim about the dissolution of a communal identity and history conjured by the mythopoetic imagination for the sake of a positivistic and rational accounting of the material conditions of the proletariat and the universal class struggle. It is very likely that Vico would have taken Fanon's side against Sartre on this issue. "The paradox for Vico is that ... [man] becomes estranged from the passionate ground of existence. In time, his literary creations become drained of their poetic content; his myths cease to provide a basis for belief." 37 However, although he regards this dissolution as inevitable, Vico also laments it and continues to hope and long for the mythopoetic age. On the other hand, Vico believes that modernity, in which positivistic and instrumental reason dominates and in which mythos is supplanted, will ultimately leads to barbarism. Vico does not embrace the linear view of time and progress that dominated Enlightenment thought but, instead, embraces a cyclical view of history in which historical epochs repeat themselves. He, therefore, believes that we must ultimately return to the age of mythopoetic imagination, in order to fulfill the cycle and to, once again, conjure community, identity, and society into Being. 
To this extent, I believe that Vico would see, in the poetry of negritude, the last great poetry of our age since it resists imprisonment by modernity and, instead, conjures identity and Being for the sake of liberation. It is interesting to note that, despite his ultimate conclusions regarding negritude, Sartre seems to agree with this idea when he states that "however far he may be from 'the black country where ancestors sleep,' the black man is closer than we are to the great period when, as Mallarmé says, 'the word creates Gods'."38 Such a notion would also be supported by Vico since, for him, "[t]he dignity of man lies not in progress for its own sake but in the creative process by which man refashions his world in each historical epoch. In this enterprise, the role of the poet is central." 39 And so I conclude with the words of the poet, Aimé Césaire.

Reason, I sacrifice you to the evening breeze. You call yourself the language of order? For me it is the lash of the whip. But oh, there is the hoarse contraband of my laughter, my treasure of saltpepper! For we hate you, you and your reason, for we appeal to the dementia praecox of the flowering absurdity of a stubborn cannibalism. Our treasures, then, are the madness that remembers, the madness that roars, the madness that sees, the madness that breaks loose. ${ }^{40}$

${ }^{1}$ Aimé Césaire, as quoted in Teodros Kiros, Explorations in African Political Thought (New York: Routledge, 2001), 109.

2 Zagorin Perez, "Vico's Theory of Knowledge: A Critique," The Philosophical Quarterly 34, no. 1 (January 1984): 15-16.

3 William J. Mills, "Positivism Reversed: The Relevance of Giambattista Vico," Transactions of the Institute of British Geographers 7, no. 1 (1982): 3.

4 A.T. Grant, "Vico and Bultmann on Myth: The Problem of Demythologizing," Rhetoric Society Quarterly 30, no. 4 (Autumn 2000): 50-52.

${ }^{5}$ Gerald H. Slusser, “Jung and Whitehead on Self and Divine: The Necessity for Symbol and Myth," in Archetypal Process: Self and Divine in Whitehead, Jung, and 
Hillman, ed. David Ray Griffin (Evanston: Northwestern University Press, 1989), 78 81.

6 Joseph Mali, The Rehabilitation of Myth: Vico's New Science (Cambridge: Cambridge University Press, 2002), 160-161.

7 See Max Horkeimer and Theodor Adorno, Dialectics of Enlightenment (New York: Continuum, 1976) and Herbert Marcuse, One-Dimensional Man (Boston: Beacon Press, 1964).

${ }^{8}$ Marina Paola Banchetti-Robino and Clevis Ronald Headley, "Introduction: Charting the Shifting Geography of Reason," in Shifting the Geography of Reason: Gender, Science and Religion, eds. Marina Paola Banchetti-Robino and Clevis Ronald Headley (Newcastle, U.K.: Cambridge Scholars Press, 2006).

9 Jane Anna Gordon, "Double Consciousness and the Problem of Political Legitimacy," in Not Only the Master's Tools: African-American Studies in Theory and Practice, eds. Lewis R. Gordon and Jane Anna Gordon (London: Paradigm Publishers, 2006), 209-212.

${ }^{10}$ Slusser, "Jung and Whitehead on Self and Divine," 86.

${ }^{11}$ Grant, "Vico and Bultmann on Myth," 50.

12 Stephen Toulmin, Human Understanding: Volume I - The Collective Use and Evolution of Concepts (Princeton: Princeton University Press, 1972), 23.

${ }^{13}$ Aimé Césaire, "Poetry and Knowledge," in Poetry in Theory: An Anthology 19002000, ed. John Cook (Oxford: Wiley-Blackwell Publishing, 2004), 284.

${ }^{14}$ Césaire, "Poetry and Knowledge," 277-281.

${ }^{15}$ Césaire, “Poetry and Knowledge,” 279-280.

${ }^{16}$ Césaire, "Poetry and Knowledge," 280-281. 
17 J'Nan Morse Sellery, “The Necessity for Symbol and Myth: A Literary Amplification," in Archetypal Process: Self and Divine in Whitehead, Jung, and Hillman, 103.

18 Jean-Paul Sartre, “What is Literature?" And Other Essays, trans. John MacCombie, introduction by Steven Ungar (Cambridge: Harvard University Press, 1988), 300. [The original essay first appeared as “Orphée Noir," preface to Léopold Sédar Senghor, Anthologie de la nouvelle poésie nègre et malgache de la langue française (Paris: Presses Universitaires de France, 1948), reprinted by Quadrige/Presses Universitaires de France (1985), ix-xliv.]

19 Patrick H. Hutton, "The New Science of Giambattista Vico: Historicism and Its Relation to Poetics," The Journal of Aesthetics and Art Criticism 30, no. 3 (Spring 1972): 361.

20 Friedrich Nietzsche, The Will to Power, trans. Walter Kaufmann and R. J. Hollingdale, ed. Walter Kaufmann (New York: Vintage, 1968), 279.

${ }^{21}$ Friedrich Nietzsche, as quoted in Alan D. Schrift, Nietzsche and the Question of Interpretation: Between Hermeneutics and Deconstruction (New York: Routledge, 1990), 134.

${ }^{22}$ Césaire, "Poetry and Knowledge," 283.

${ }^{23}$ Louis Simon, "The Politics of Complex Faith: Wilson Harris's Resurrection at Sorrow Hill," The Journal of Commonwealth Literature 31, no. 2 (1996): 81-82.

${ }^{24}$ Sartre, “Black Orpheus,” 295-297.

${ }^{25}$ Sartre, “Black Orpheus,” 308.

${ }^{26}$ Césaire, "Poetry and Knowledge," 284.

${ }^{27}$ Hutton, "The New Science of Giambattista Vico," 361.

${ }^{28}$ Sartre, “Black Orpheus," 290.

${ }^{29}$ Sartre, “Black Orpheus," 293. 
30 Sartre, “Black Orpheus," 294.

31 Sartre, “Black Orpheus," 302-303.

32 Sartre, "Black Orpheus," 303.

${ }^{33}$ Hutton, "The New Science of Giambattista Vico," 365.

${ }^{34}$ Sartre, “Black Orpheus," 318.

${ }^{35}$ Sartre, “Black Orpheus,” 328.

${ }^{36}$ Frantz Fanon, Peau noire, masques blancs, preface (1952) and postface (1965) by Francis Jeanson (Paris: Éditions du Seuil, 1952), 128-132.

${ }^{37}$ Hutton, "The New Science of Giambattista Vico," 366.

${ }^{38}$ Sartre, “Black Orpheus,” 308.

${ }^{39}$ Hutton, "The New Science of Giambattista Vico," 366.

${ }^{40}$ Aimé Césaire, from Notes of My Return to My Native Land, as quoted in Janheinz Jahn, Muntu: African Culture and the Western World, trans. Marjorie Greene (New York: Grove Press, 1990), 143. 